\title{
REFLECTIVE PRACTICES OF TEACHER EDUCATORS IN PUNJAB: A NARRATIVE PERSPECTIVE \\ Tanzeela Akram ${ }^{1 *}$, Azhar Majeed Qureshi \\ ${ }^{1 *} \mathrm{Ph} . \mathrm{D}$., Scholar, University of Education, Lahore, Pakistan; ${ }^{2}$ Assistant Professor, University of Education. Lahore, Pakistan. \\ Email: ${ }^{1 *}$ tanzeela.akram@ue.edu.pk, ${ }^{2}$ azhar.majeed@ue.edu.pk
} Article History: Received on $26^{\text {th }}$ May 2021, Revised on $11^{\text {th }}$ June 2021, Published on $21^{\text {st }}$ June 2021

\begin{abstract}
Purpose of the study: Reflective practices are considered very important and influential for teacher training and professional development. This study was conducted by using a narrative perspective. The main aim of this study was to explore the role of reflective practices in building teacher educators' professional lives. Their stories were explored to understand what is needed to become an effective teacher educator.
\end{abstract}

Methodology: The current research involved six teacher educators from GCETs selected purposively as research participants. Semi-structured interviews were used as data collection instruments. Teacher educators who have a minimum of ten years of experience were interviewed. After gathering stories, the researchers build categories and themes from interview data. The narratives of teacher educators were reconstructed through analysis and discussion.

Main Findings: The findings of the current research reveal that reflective practices can play a very effective role in the professional grooming of teacher educators. The effective use of reflective practice tools is significant in building these practices. It is implicated by the study findings that novice teacher educators and future teacher educators can learn from the experiences of experienced teacher educators.

Novelty: This research will help the administration to know about problems that teacher educators face while using reflective practices. Future researchers can be helped to explore the ways that how the reflective practices-related challenges and problems can tackle. Moreover, how the reflective practices of school teachers and college teachers can be made more effective.

Keywords: Reflective Practices, Teacher Educators, Professional Development, Narrative Perspective.

\section{INTRODUCTION}

Reflective practices in teaching ensure an additional, accurate, and significant condition of teaching and reinforce performance to teachers to engender change in to improve their teaching practices. It plays a vital role in the professional development of teachers (Colognesi, Deprit, Coppe, Nieuvenhoven, Marz \& Hanin, 2021; Gay \& Kirkland, 2003; Impedovo \& Malik, 2016; Rolfe, Freshwater, \& Jasper, 2001; Schon, 1996). Through reflective practices, teachers can improve their self-knowledge and can consider their performance (Abell, Bryan, \& Anderson, 1998; Akbari, 2007; Gay \& Kirkland, 2003; Yanuarti \& Treagust, 2016). Therefore, it is recommended that teacher educators should reflect on their teaching experiences and should have the capability to use this information generated from self-reflection to increase their professional learning. Reflective practices are the practices of teacher educators through which they can analyze their experiences of teaching by thinking and rethinking before, during, and after class activities (Korthagen, 2004).

Teacher educators should be very much committed to their professional development, and reflective practices are very important for the professional grooming of teacher educators. Reflective practices develop skills like logical thinking, decision making, and metacognition (Zahid \& Khanam, 2019; Goodley, 2018; Bahr, 2016; Avalos, 2011; Cooper \& Olson, 1996 Adler, 1991). Reflection on teaching is frequently mentioned as a fundamental practice for personal and professional development. Roots of reflection are in the glorious work of Dewey. About 100 years ago Dewey introduced the concept of reflection in his great work known as How We Think (Dewey, 1933). Dewey is the most frequently referred thinker in literature written on the role of reflection in students learning and teacher education. He is considered as an originator of the concept of reflection, as a philosopher who introduced reflection as a source of learning. He described many modes of thinking that are valuable for learning like consciousness, imagination, and belief. The concept in which he was more interested in the reflection (Kember, Leung, Jones, Loke, McKay, Sinclair, Tse, Webb, Wong \& Yeung, 2000). Reflection is a process that provides the learners deeper understandings of their experiences, at the base of which they can find connections to the other experiences and enhance their learning, and moves towards achievement of their goals and desired ends (Krishnamurthy, 2007; Mason, 2012; Jones \& Jones, 2013; $\underline{\text { Sahin \& Usta Gezer, 2014). }}$

Things expected from teacher educators are that they should be self-aware and reflective. They should always be involved in refining their knowledge through the reflection of their practices. And thus, they will work for promoting thinking in trainees as well. Teacher education and teaching are very challenging and sensitive activities (Johnson, Cooper, Cartwright, Donald, Taylor \& Millet, 2005). And because of the challenging and social nature of teaching, teachers are committed to their profession emotionally and personally and they enjoy their work. It is pretty evident that 
the challenges and problems that teacher educators face every day of their professional life, demand from them to reflect continuously on their teaching experiences and find solutions for the problematic situations.

Student teachers develop professional competencies and get knowledge of teaching from teacher educators. Teacher educators are guides for trainee teachers (Lunenberg, Korthagen, \& Swennen, 2007). Therefore, it is crucial to explore the approaches of teacher educators they use to train future teachers. Teacher educators use a complex combination of techniques and strategies to teach student teachers (Postareff, Katajavuori, Ylanne, \& Trigwell, 2008). Reflective attitude and experience play vital role in professional grooming (Kolar \& Dickson, 2002; Yost \& Mosca, 2003; Freese, 2006; Amobi, 2006; Rahimi \& Weisi, 2018). Bullough (2008) argued that if the experiences of the teacher educators are explored and written in a way that reflects the reflective practices of teacher educators, it will work for future teachers to guide them.

\section{LITERATURE REVIEW}

The concept of reflective practices and reflections is rooted in the work of great philosopher John Dewey (1933). He described that reflection transpires while an individual faces a challenging and confusing situation (Almusharraf, 2020). The views that when professionals are involved in thinking about what they are doing and how they are doing, they are in the process of reflection (Farrel \& Kennedy, 2019). Reflectivity is a dialogue of thinking and doing through which professionals become more skillful. Reflective practices help the professional to develop themselves professionally, helps the learners to learn more effectively (Pardo \& Tellez,2015). Many studies have been conducted on the relationship between professional development and reflective practices (Korkko, Ammala \& Turunen, 2016; Kimmelmann \& Lang, 2019; Akcan, 2016; Muradkhania \& Shirazizadeh, 2017). Through reflection, professionals analyze their feelings of what they did, evaluate their experiences and make judgments (Reis-Jorge, 2007; Kayapinar, 2016).

Reflection plays a critical role in the ongoing learning of professionals. As a result of using reflection, professionals become self-governing and self-directed (Jesper,2003; Toom, Husu \& Patrikainen, 2015; Bradbury, Fitzgerald \& Connor, 2020; Lianshenko, 2020). Bartlett (1990) views reflection as a process that enables practitioners to think broadly and work for more significant goals. Teachers become responsible and self-evaluators when they become reflective practitioners. Lieberman \& Miller (2000) argued that reflective practices, reflections, and reflective inquiry are processes of professional and personal development.

Reflective practitioners have some characteristics that differentiate them from others; they are open-minded, responsible, self-aware, and more responsible (Farrell, 2008). Reflective practices have many benefits when used by practitioners. Branch \& Paranjape (2002) pointed out that through reflection, the professionals get the awareness of their weaknesses and strengths, they face the challenges with a broader outlook and better understand the possible solutions of problems. Through reflection, teachers can better understand their professional deficiencies and work for areas of improvement for their professional grooming (Holewik, 2020). So, professionals can use reflective practices to improve their teaching, by raising questions on their teaching experiences consciously (Brockbank \& McGill, 2007; Sahoo \& Pany, 2020). Reflective practice has also been employed via tools such as diaries, narrative reflections, and mentoring meetings. (Hussein, Jamal \& Sadi, 2020). To expand the superiority of education, it is a need to develop the excellence of teaching, and for this, teacher educators may involve themselves in the reflective practices that make them mindful of their strengths and weaknesses and they can train future teachers effectively.

This study used the narrative inquiry method to explore the influences of reflective practices of teacher educators on their professional grooming. Teacher educators play a vital role in the training of future teachers (Afghani \& Ferdeowsi, 2015). Reflection works as a tool of professional development; it is a process of learning from experiences and getting guidelines for future practices (Ukrop, Valdemar, \& Nahyba,2018). Akram and Hassan (2018) described that experienced teachers reflect on their teaching practices throughout their professional life. They apply sets of different methodologies to solve their problems. Future teacher educators can get benefit from the experiences of expert teacher educators. So, this research may be helpful for future teacher educators to understand the worth of reflective practices in professional life.

The research questions that guided this study are:

- How the use of reflective practices played a role in building teacher educators' professional lives?

- What do the narratives of six teacher educators reveal about the significance of reflective practices in their professional lives?

\section{METHODOLOGY OF THE RESEARCH}

The primary purpose of the present study was to have an in-depth understanding of the experiences of teacher educators about the use of reflective practices in their professional lives, so the nature of this study was qualitative. The essential characteristic of qualitative research is that researcher attempts to understand, how people construct reality at the base of their experiences (Merriam, 2002). Within the qualitative framework, researchers found that narrative research would be a suitable methodology for the current study. It enabled the researchers to answer the research questions of the study. 
Narrative research allowed the researchers to understand participants' experiences about reflective practices and the impact of these experiences on their professional lives. The basic premise of narrative research is that human beings give meanings to their own experiences and narrative researchers use stories to investigate the ways human experiences the world (Connely \& Clandinin, 1990). Narratives may take many forms: oral, written, or visual, to provide insight that befits the complexity of human lives (Josselson, 2011). Essentially this is a focus on how individuals ascribe meaning to their experiences, especially (Cortazzi, 1993). That's why researchers selected narrative research design as the primary purpose of the present study was to explore the experiences of teacher educators about "reflective practices and their professional lives". The researchers wanted to bring the experiences of teacher educators about reflective practices to the forefront.

A significant reason for opting narrative approach for the proposed research is that individuals love to tell stories of their life experiences. In narrative studies, researchers attempt to explore how humans experience the world and collect data in the form of narratives (Clandinin \& Connelly, 1990). As in this approach, the researcher does not see reality with the lens of objectivity and certainty (Baguley, Findlay \& Kerby, 2015). So, in narrative research, the reality is constructed by the experiences of the narrators (Pinniger \& Daynes, 2007). It gives an in-depth understanding of the phenomena to the researcher (Creswell, 2012), as narrative data differs from the data that is gathered from other sources where respondents have to choose a response from given options (Polkinghorne, 1988). That's why this methodology seems suitable for current research as the purpose of the proposed study is to have an in-depth understanding of the effectiveness of reflective practices, to understand the challenges and problems teacher educators face while using reflective practices in their professional lives in the light of the experiences of teacher educators.

Participants' stories are considered the primary source of data collection in narrative research, so the participants play a more active role in narrative research. It is research with people rather than on people (Watson, 2014). The narrator in narrative research is very active and is the pivot of the study (McALPINE, 2016). The narrative studies empower the research participants (Garvis, 2015). Through their narratives, the participants give meanings to their experiences and reveal themselves (Butina, 2015). In narrative research, the researcher communicates the participants' stories with rich layers of information to a larger group of readers (Wang \& Geale, 2015; Andrews, Molly, Squire, Corinne \& Tambokou, Maria, 2008). Researchers followed the criteria given by Riessman (2002), according to which narrative researchers should try to hear as many voices of the participants as possible. Therefore, the researchers need to share the narratives constructed from interviewed data with the participants for member checking, so that if some details are missing in the narratives can be expanded by the participants (Polkinghorne, 1995). So, the researchers followed all necessary measures to ensure the trustworthiness of the narratives.

Learning about people and their lives within the context in which they live is one of the main aims of qualitative research. When interpreting human behavior, qualitative researchers emphasize the importance of considering various aspects of the environment, including physical, ethnic, historical, ideological, and gender aspects (e.g., Bruner, 1990; McAdams, 1993; Polkinghorne, 1988). In the current study, the researchers used the three-sphere context model introduced by Zilber, Tuval-Mashiach \& Lieblich (2008). Three contexts, according to Zilber, Tuval-Mashiach \& Lieblich (2008) are the immediate inter-subjective relationships (the moods, intentions, and motivations involved when telling a specific narrative; and the relationship between interviewee and interviewer), the collective social field context (relates to the socio-historical context), the broad cultural meaning systems (webs of meaning that reflect cultural themes and beliefs). The current study focused on immediate inter-subjective relationships where the interviewer and interviewee relationship matter as the researchers are teacher educators themselves, so there is a strong bond between the researchers and research participants.

Researchers selected six in-service teacher educators of Punjab purposively. In the first stage, the researcher met sixteen teacher educators and prepared their profiles, and after that, only those teacher educators were selected who have a minimum of ten years of experience as a teacher educator and who can give rich information. Another reason for which these participants were selected was that they were open to sharing their experiences. At the time of the study, all these participants, five of whom were females and one was male, were working in different institutes of teacher education. Participants were given pseudonyms that were used throughout the study. Following is a brief description of the profile of each participant.

- Zara: Zara has been working as a teacher educator for ten years, and before starting her job as a teacher educator, she was a school teacher. Her qualification is M.Phil. Her subject is Urdu. She is a very dedicated teacher educator. She enjoyed her job as a teacher educator and said that as a teacher educator, she learned a lot. She said that her students' feedback is a source of inspiration for her.

- Saima: Saima has been working as a teacher educator for ten years and before joining as a teacher educator, she worked as a subject specialist in a high school. She is an M.Phil. scholar. She got several pieces of training as a teacher educator from British Council. She said that she loves her profession and performs her duties full of dedication.

- Fatima. She has been working as a teacher educator for sixteen years. She is an M.Phil. in English. Her story is very vibrant as she has vast experience of teaching. She joined the profession of teaching as EST (Elementary School 
Teacher), then worked as SST (Secondary School Teacher), then joined as SS (Subject Specialist). Throughout her career as a teacher, she continued her studies. And now working as a teacher educator for sixteen years. Overall, she has been in the field of teaching for thirty-five years. Despite her age and health issues, she is a very energetic and passionate learner who wants to learn more and more.

- Faria: She has been working as a teacher educator for eleven years, before working as a teacher educator she served as a subject specialist for twelve years. Her qualification is an M.Ed. Her overall teaching experience is twenty-three years. She said that she always has an excellent relationship with her students and always takes feedback from her students. She said that she always tried to deliver something up to date to her students.

- Saira: She has been working as a teacher educator for twelve years and worked as a subject specialist for two years before joining GCET. She is an M.Phil. in Education. She is a very passionate teacher educator. She said that she always wants to see her students well motivated and ready to learn. For that purpose, she invites motivational speakers from time to time to talk with students.

- Ali. He has been working as a teacher educator for ten years and also served in different private schools for five years before joining as a teacher educator. He is an M.Phil. in Education. He said that he has a strong habit of preparing portfolios and always shares his teaching experiences with his senior colleagues and gets feedback from them. That helps him a lot.

The researchers used one of the most commonly used data collection tools in narrative research: semi-structured interviews (Altan \& Lane, 2018). Rather than a set of strictly pre-determined questions, the researchers used a more open format to prompt participants to share their experiences regarding reflective practices. Researchers took additional field notes to account for additional information that could not be digitally recorded. Two in-depth interviews were conducted with each participant. Each interview lasted from one to two hours and was recorded with the permission of the participants. The first interview was related to the reflective practices-related experiences. After conducting the first interview, the researcher transcribed the interviews. Researchers reviewed each interview separately. At the second phase of the interviews, the transcribed interview data was shared with every participant for member check, and further deeper details and information was being collected. Participants reviewed the transcribed data and then shared the more specific information about reflective practices they use that were missing, and they could not share at the first phase. Then researchers visited the participants a third time for the following purpose: to obtain participants' feedback and review on final reconstructed narratives. The researchers selected the following major themes at the base of the reconstructed narratives of the participants: learning from experiences, reflective practices played a role in professional grooming, reflective practices help to modify teaching practices.

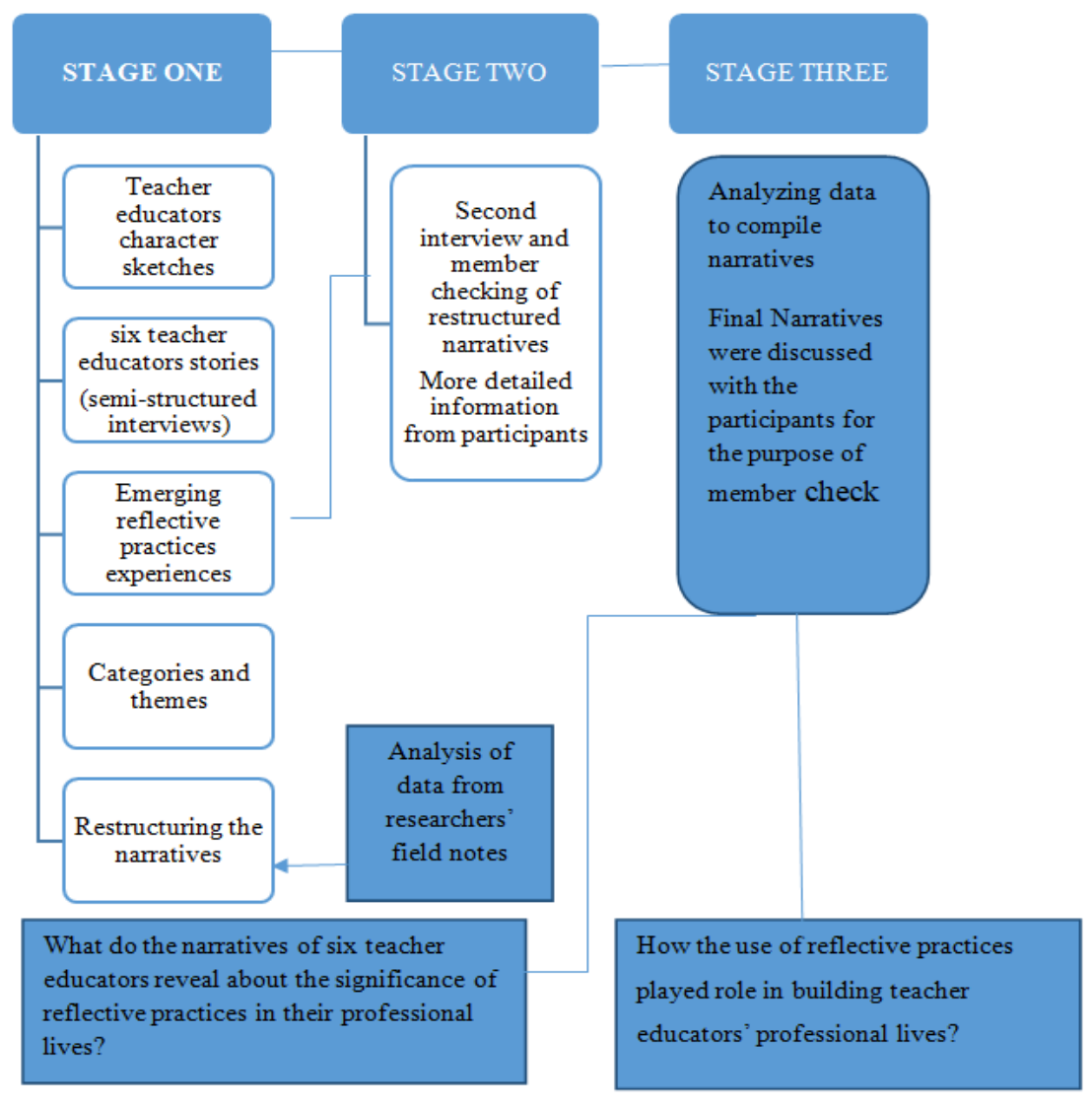

Figure 1: Visual model of research design 


\section{DATA ANALYSIS}

For data analysis of the study, researchers kept one thing in mind that what do the narratives of participants tell about their experiences related to the reflective practices. Narrative analysis is different from the other types of qualitative researches. A significant characteristic of narrative analysis is restoring or reconstructing the narratives of participants (Creswell, 2012). Researchers gathered the stories from research participants about their experiences, analyzed the stories for key points, and then rewrote the stories in chronological order. Researchers followed the three steps of reconstruction of the narratives i.e. after conducting interviews, at the first phase, audio-recordings were transcribed and re-transcribed, to complete the initial coding, transcripts were coded by hand, using line by line and incident to incident techniques and additionally field notes were being used to produce six narratives. Initial codes were made after transcribing the interviews, and then by keeping in view the emerged categories and themes, the researchers construct six narratives (Gay, Mills \& Airasian, 2012). Researchers first construct the narratives, then at the second phase of the interview discuss those narratives with the participants. Then deconstruct those narratives in the light of the feedback of the participants, and then reconstruct the narrative; by gaining more details in the second interview (Josselson, 2011), as construction and reconstruction of the narratives in narrative research is an ongoing process (Clandinin \&Connelly, 2000). So, the researchers in the current study followed the pattern strictly. Then researchers compare the six narratives to discover consistencies and inconsistencies in the narratives.

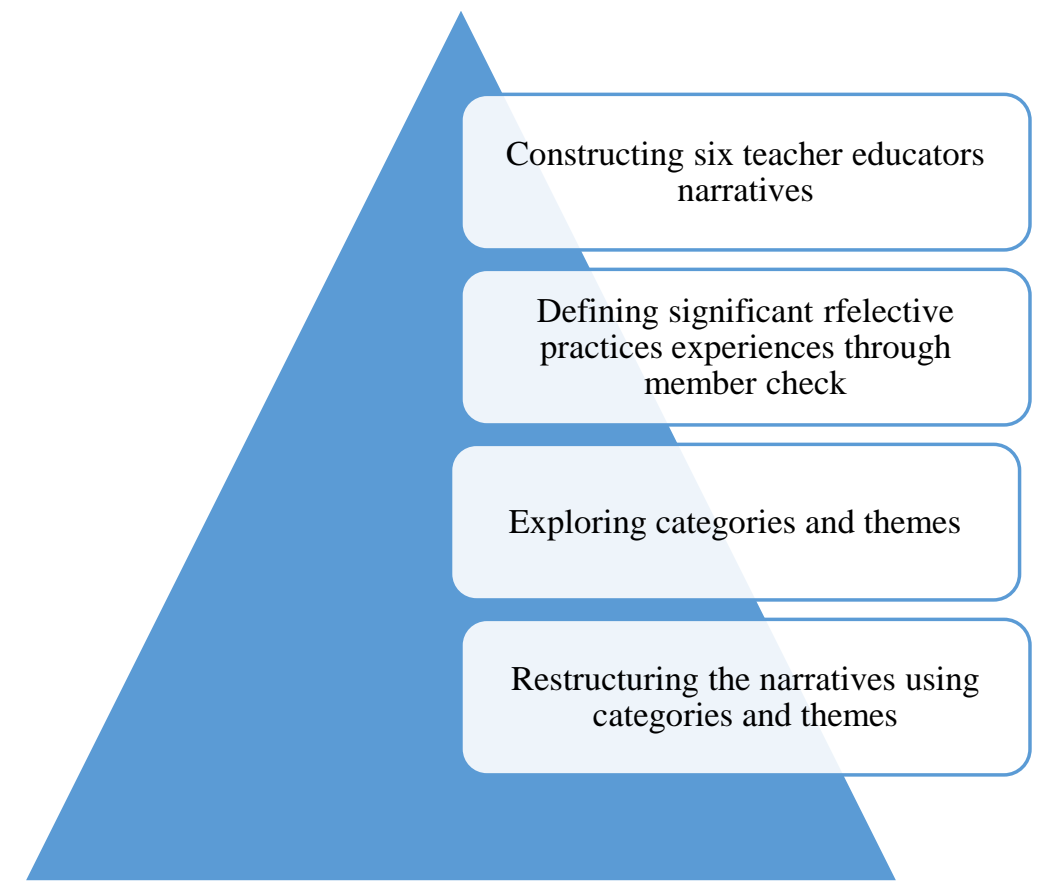

Figure 2: Process of narrative data analysis

\section{FINDINGS}

The analysis of the narrative data revealed that the participants' reflective practice-related experiences consist of three major themes: learning from experiences, reflective practices played a role in professional grooming, reflective practices help to modify teaching practices. Learning from experience refers to that the teacher educators learn from their own experiences. When teacher educators reflect on their practices, they learn a lot. All participants said that their reflections on their work played a crucial role in their professional grooming. Professionals use reflective practices to improve their teaching, by raising questions on their teaching, consciously (Brockbank \& McGill, 2007; Sahoo \& Pany, 2020).

The results of narrative data explored that reflective practices played a significant role in teacher educators' professional grooming. The analysis of the six narratives showed similarities in participants' responses about self-evaluation/selfreflection. All six participants said that their self-evaluation played a vital role in this professional grooming as, through self-evaluation, one can come to know about his/her strengths and weaknesses.

- I think self-evaluation played a significant role in my professional grooming. If you want to give your best to your students and positively change them, you want to attain your goals, and evaluate yourself (Faria).

- I think self-evaluation works a lot in my improvement as a professional (Saira).

- I always think; about my shortcomings and mistakes that I should not repeat next time. I always learned from my own (Fatima).

- I have a habit of writing reflections about my own teaching experiences. And then I plan accordingly (Ali). 
- I always think about my previous teaching experiences and the things that make me dissatisfied. I feel it should not be like this, then I change my teaching (Zara).

When the teacher educators were asked about reflection in action, their responses indicated that they were involved in the practice of reflection-in-action somehow. They all agreed that sometimes reflection-in-action is necessary to keep your students with you and get them involved.

- Hum sometimes happens like this we have to change our strategy, and it brings improvement (Zara).

- Yes, it becomes need sometimes. By keeping in view, the mood, motivation of the students, you need to switch on other activities and techniques (Fatima).

- Yes, I always do this according to the class situation (Faria).

- It becomes essential sometimes (Saima).

- Yes, it is my practice as I have to see the students' moods (Ali).

Analysis of the narrative data revealed that all six participants get involved in reflection on action.

When they were asked about it, they said that it is very imperative to reflect on your previous teaching experiences. At the base of it, you improve your future teaching activities (improve your lesson plans, enrich the course material, and improve strategies of teaching).

- It happens, it makes a difference, and sometimes I experience that if I do not do this and do not think about the class after finishing it, then that weakness remains the same (Fatima).

- After delivering some lessons, you feel happy and satisfied and sometimes you are not confident after class (Saira).

- After leaving class, when I think that I could not do justice with my students, then I feel discomfort in my heart (Faria).

- After class, I always think about my performance, whether it was good, productive (Saima).

- Yes, I always do this. It is automatic, like the process for me. I think about the positives and negatives of my teaching (Ali).

- I always do it. I recall after class that how I started today's lesson and how I delivered the main content, and how I ended up in the class (Zara).

Analysis of the narratives of teacher educators revealed that teacher educators use different types of reflective practices for their professional grooming.

- I take feedback from my students that what should I do for your better understanding and sometimes, I discuss my teaching-related experiences with my colleagues (Fatima).

- I have a habit of developing a portfolio. I collect all the material that I have used for teaching and then reflect on that (Ali).

- No, I am not in the habit of it. I take notes of the things and discuss them with my colleagues; it helps me a lot (Saira).

- Not diary and reflective journal as such, but I am in habit of taking short notes for my guidance (Ali).

Fatima and Saira said that they share their teaching experiences with their colleagues to have feedback and guidance. Ali said that he always develops portfolios and writes a reflective journal for his guidelines and improvement. And as discussed at the start of the analysis, all six teacher educators firmly believe in self-reflective practices, and this is considered very significant for professional grooming by all six participants.

Teacher educators shed light on some challenges they face while using reflective practices. According to Faria and Fatima, these challenges were lack of communication, multitasking, lack of responsibility, and time management.

- I think time management is a big issue in this regard as you have to spend more and more time (Faria).

- Time and multitasking. As we are busy in many places, then it becomes difficult to manage it. So, I think the administration should play a role in it and should distribute responsibilities by keeping in view the workload of the teachers so that they can concentrate on their teaching. Sometimes it happens that reflection is not possible daily (Fatima).

\section{DISCUSSION}

The findings of this study hold worthwhile/practical implications for practice for teacher educators, as the results of the study explored that the reflective practices played a significant role in the professional lives of teacher educators, so teacher educators should be encouraged about the use of reflective practices. Further training should be provided to teacher educators to use different kinds of reflective practices as analysis of narrative data indicated that teacher 
educators use only a few types of reflective practices as portfolios, students' feedback, peer feedback, and self-reflection; there are other tools of reflection as well those can be used very effectively such as diaries, narrative reflections, and mentoring meetings. Additional tools are peer observation, student feedback, audio recording, peer coaching, action research, reflective journals, and video recording (Lee, 2005; Hussein, Jamal \& Sadi, 2020). But most of the respondents did not use all these reflective practice tools.

The findings of the study explored that reflection in action helped teacher educators a lot in improving their teaching. Reflection is a process that provides the learners deeper understandings of their experiences, at the base of which they can find connections to the other experiences and enhance their learning (Krishnamurthy, 2007; Mason, 2012; Jones \& Jones, 2013; Sahin \& Usta Gezer, 2014).

The study explored that colleagues' feedback, students feedback, portfolios, and self-evaluation are practical tools that can play a role in the enhancement of teaching competencies as reflection is associated with ongoing learning that is resulted in the development of the professionals who are self-governing, trained, and self-directed; in fact, reflection is related with the enhancement of motivation among professionals to improve their professional skills and to fill the gap between theory and practice (Jesper,2003; Toom, Husu \& Patrikainen, 2015; Bradbury, Fitzgerald \& Connor, 2020; Lianshenko, 2020). Teacher educators use reflective practices in different situations according to their needs and improve the teaching-learning situation as reflection occurs when an individual faces a challenging and confusing situation (Almusharraf, 2020). Analysis of the teacher educators' narratives explored that teacher educators face problems while using reflective practices. They reported that time management and multitasking is a major hindrance in the use of reflective practices. The administration should take necessary steps to facilitate the teacher educators in this regard.

\section{CONCLUSION}

The finding of this current research shed light on the effectiveness of reflective practices among teacher educators. This study will be helpful to enhance future teacher educators' understanding regarding the worth of reflective practices in teaching. Moreover, this research will give awareness to teacher educators that there are several reflective practices other than peer feedback, students feedback and portfolio preparation, which can be used effectively. Novice teacher educators and future teacher educators will learn from the experiences of senior teacher educators. This research will help the administration and policymakers to understand the problems that teacher educators face while using reflective practices so that teacher educators can be facilitated.

\section{LIMITATION AND STUDY FORWARD}

The current study was conducted to find out the reflective practices of teacher educators and to reveal the significance of reflective practices in the professional lives of teacher educators. Further studies based on different methodologies can be conducted to explore the way, that how the reflective practices-related challenges and problems can be tackled. Moreover, studies can be conducted to find out the reflective practices of school teachers and college teachers, in this way, different insights may be gained about the effectiveness of reflective practices.

\section{AUTHORS CONTRIBUTION}

Tanzeela Akram: Work on literature, data collection, and analysis.

Azher Majeed Qureshi: Review of the article after completion and correspondence with the journal.

\section{REFERENCES}

1. Abell, S. K., Bryan, L. A. \& Anderson, M. A. (1998). Investigating pre-service elementary science teacher reflective thinking using integrated media case-based instruction in elementary science teacher preparation. Science Education, 82(4), 491-510.

2. Adler, S. (1991). The reflective practitioner and the curriculum of teacher education. Journal of Education for Teaching: International research and pedagogy, 17(2), 139-150. https://doi.org/10.1080/0260747910170203

3. Afghari, A. \& Ferdowsi, M. (2015). The effects of reflective teaching on teachers' performance. International Journal of Educational Investigations, 2(6), 20-31.

4. Ahmed, S. N., Abbas, F. \& Naz, F. (2020). Historical development of orthography in English and impact of computer-mediated communication (CMC) on the emerging orthographic patterns in English. PalArch's Journal of Archeology of Egypt 17(11), 162-175.

5. Ahmed, S., Abbas, F., Jalil, M. K. \& Ahmad, M. (2019) Language Anxiety as a Detrimental Factor in English Language Learning: A Survey of Religious Madaris. Al Qalam, 24 (2), 346-363.

6. Akbari, R. (2007). Reflections on reflection: A critical appraisal of reflective practices in L2 teacher education. System, 35(2), 192-207. https://doi.org/10.1016/j.system.2006.12.008

7. Akcan, S. (2016). Novice non-native English teachers 'reflections on their teacher education programs and their first years of teaching. PROFILE Issues in Teachers' Professional Development, 18(1), 55-70. https://doi.org/10.15446/profile.v18n1.48608 
8. Akram.S. \& Hassan, S.(2018). Reflective view on career: A case study, Pakistan Journal of Social and Clinical Psychology, 16(01), 27-38.

9. Almusharraf, A.M. (2020). Student teachers' development of reflective practice concerning teaching philosophy and peer observations. Arab World English Journal, 11(4), 547-564. https://doi.org/10.240 93/awej/vol11no4.35

10. Altan, L. \& Lane, J.F. (2018). Teacher's narratives: A source for exploring influences of teachers, significant life experiences on their dispositions and teaching practices. Teaching and Teacher Education, 74(2018), 238248. https://doi.org/10.1016/j.tate.2018.05.012

11. Amobi, F.A. (2006). Beyond the call: Preserving reflection in the preparation of "Highly Qualified" teachers. Teacher Education Quarterly, 33(2), 23-35.

12. Andrews, Molly, Squire, Corinne \& Tambokou, Maria. (2008). Doing narrative research. London: Sage. https://doi.org/10.4135/9780857024992

13. Avalos, B. (2011). Teacher professional development in Teaching and Teacher Education over ten years. Teaching and Teacher Education, 27(1), 10-20. https://doi.org/10.1016/j.tate.2010.08.007

14. Baguley, M.M., Findlay, Y.S. \& Kerby, M.C. (2015). Meanings and Motivation in Educational Research, Routledge: Taylor and Francis Group: London. https://doi.org/10.4324/9781315749631

15. Bahr, N. (2016). Australian Education Review: Building Quality in Teaching and Teacher Education, Camberwell: Australian Council for Educational Research.

16. Barlett, L. (1990). Teacher development through reflective teaching. In J. C. Richards \& D. Nunan (Eds.), Second language teacher education (pp. 202-214). Cambridge, UK: Cambridge University Press.

17. Bhatti, A.M., Abbas, F. \& Rana, A.M.K. (2020). An Empirical study of learning styles used by undergraduate English learners in public sector colleges in Pakistan. Elementary Education Online, 19 (3), 1864-1875.

18. Bradbury, O. J., Fitzgerald, A., \& O'Connor, J. P. (2020). Supporting pre-service teachers in becoming reflective practitioners using conversation and professional standards. Australian Journal of Teacher Education, 45(10). 18-34. https://doi.org/10.14221/ajte.2020v45n10.2

19. Branch, W. T., \& Paranjape, A. (2002). Feedback and reflection teaching methods for clinical settings. Academic Medicine, 77(12), 1185-1188. https://doi.org/10.1097/00001888-200212000-00005

20. Brockbank, A. \& McGill, I. (2007). Facilitating reflective learning in higher education. Berkshire: Open University Press.

21. Bruner, J. (1990). Acts of meaning. Cambridge, MA: Harvard University Press.

22. Bullough, R.V. (2008). Counter narratives: studies of teacher education and becoming and being a teacher. Albany, NY: State University Press of New York Press.

23. Butina, M. (2015). A Narrative Approach to Qualitative Inquiry, Clinical Laboratory Science, 28(02), $190-196$. https://doi.org/10.29074/ascls.28.3.190

24. Clandinin, D. J., \& Connelly, F. M. (1990). Stories of experience and narrative inquiry, Educational Researcher, 19(5), 2-14. https://doi.org/10.3102/0013189X019005002

25. Clandinin, D. J., \& Connelly, F. M. (2000). Narrative inquiry. San Francisco, CA: Jossey- Bass.

26. Colognesi, S., Deprit, A., Coppe, T., Nieuwenhoven, C.V., März, V., \& Hanin, V.(2021). Developing Student Teachers' Reflexivity Toward Their Course Planning: Implementation of a Training Program Focused on Writing and Reflective Skills, SAGE Open, The Author(s), April-June 2021, 1-14, https://doi.org/10.1177/2 1582440211016897

27. Cooper, K., \& Olson, M. R. (1996). The multiple \& I's' of teacher identity. In M. Kompf, W. R. Bond, D. Dworet, \& R. T. Boak, Changing research and practice: Teachers professionalism, identities, and knowledge (pp. 78-89). London: Falmer Press.

28. Cortazzi, M. (1993). Narrative analysis. London: The Falmer Press.

29. Creswell, J. W. (2012). Educational research: Planning, conducting, and evaluating quantitative and qualitative research (4th ed.). Boston, MA: Pearson.

30. Dewey, J. (1933). How we think. Buffalo: NY: Prometheus Books.

31. Farrell, T. S. C. (2008). Reflective practice in the professional development of teachers of adult English language learners. Brock University, Ontario, Canada: Caela Network.

32. Farrell, T.S.C \& Kennedy, B. (2019) Reflective practice framework for TESOL teachers: one teacher's reflective journey. Reflective Practice, 20(1), 1-12. https://doi.org/10.1080/14623943.2018.1539657

33. Freese, A.R. (2006). Reframing one's teaching: discovering our teacher selves through reflection and inquiry. Teaching and Teacher Education, 22(1), 100-119. https://doi.org/10.1016/j.tate.2005.07.003

34. Garvis, S. (2015). Narrative Constellations: Exploring Lived Experience in Education. Boston: Sense Publishers. https://doi.org/10.1007/978-94-6300-151-9

35. Gay, G., \& Kirkland, K. (2003). Developing cultural critical consciousness and self-reflection in preservice teacher education. Theory into Practice, 42(3), 181-187. https://doi.org/10.1207/s15430421tip4203_3

36. Gay, L.R., Mills, G.E., \& Airasian, P.W. (2012). Educational research (10 ${ }^{\text {th }}$ ed.). Pearson Education, Inc: USA.

37. Gibbs, G. (1988). Learning by Doing: A guide to teaching and learning methods. Further Education Unit. Oxford Brookes University: Oxford. 
38. Goodley, C. (2018). Reflecting on being an effective teacher in an age of measurement. Reflective Practices, 19(01), 167-178. https://doi.org/10.1080/14623943.2018.1437401

39. Holewik, K. (2020). Peer Feedback and Reflective Practice in Public Service Interpreter Training. Theory and Practice of Second Language Acquisition, 6(2), 133-159. https://doi.org/10.31261/TAPSLA.7809

40. Hussain,H.A.R.A., Jamal, D.A.H.A. \& Sadi,I.(2020). Studens' Reflective Journals and Creative Writing in EFL, Universal Journal of Educational Research, 7(2), 3484-3495. https://doi.org/10.13189/ujer.2020.080823

41. Impedovo, M. A., \& Khatoon Malik, S. (2016). Becoming a reflective in-service teacher: Role of research attitude. Australian Journal of Teacher Education, 41(1). https://doi.org/10.14221/ajte.2016v41n1.6

42. Iqbal, A. Ali, M.S., Abbas, F Shah, M.A.H. \& Anjum, S. (2020). A Study of Work-Family Conflict among Elementary School Teachers. International Journal of Innovation, Creativity and Change. 14(10), 198-209.

43. Jasper, M. A. (2003). Nurses' perceptions of the value of written reflection. Nurse Education Today, 19(6), 452-463. https://doi.org/10.1054/nedt.1999.0328

44. Johnson, S., Cooper, C., Cartwright, S., Donald, I., Taylor, P., \& Millet, C. (2005). The experience of workrelated stress across occupations. Journal of Managerial Psychology, 20, 178-187. https://doi.org/10.1108/02 $\underline{683940510579803}$

45. Jones, J., \& Jones, K. (2013). Teaching reflective practice: Implementation in the teacher-education Setting. Teacher Educator, 48(1), 73-85. https://doi.org/10.1080/08878730.2012.740153

46. Josselson, R . (2011). Five Ways of Doing Qualitative Analysis, London: Guilford Press.

47. Kayapinar, U. (2016). A study on reflection in in-service teacher development: Introducing reflective practitioner development model. Educational Sciences: Theory \& Practice, 16, 1671-1691.

48. Kember, D., Leung, D.Y.P., Jones, A., Loke, A.Y., McKay, J., Sinclair, K., Tse, H., Webb, C., Wong, F.K.Y., Wong, M. \& Yeung, E. (2000). Development of a questionnaire to measure the level of reflective thinking. Assessment \& Evaluation in Higher Education, 25(4), 381-394. https://doi.org/10.1080/713611442

49. Kimmelmann, N., \& Lang, J. (2019). Linkage within teacher education: Cooperative learning of teachers and student teachers. Journal of European Teacher Education, 42(1), 52-64. https://doi.org/10.1080/02619 768.2018 .1547376

50. Kolar, C., \& Dickson. S.V. (2002). Pre-service general educators' perceptions of structured reflective logs as viable learning tools in a university course on inclusionary practices.Teacher Education and Special Education, 25(4), 395-406. https://doi.org/10.1177/088840640202500408

51. Körkkö, M., Kyro-Ammala, O., \& Turunen, T. (2016). Professional development through reflection in teacher education. Teaching and Teacher Education, 55(1), 198-206. https://doi.org/10.1016/j.tate.2016.01.014

52. Korthagen, F.A.J. (2004). In search of the essence of a good teacher: towards a more holistic approach in teacher education, Teaching and Teacher Education, 20(2004), 77-97. https://doi.org/10.1016/j.tate .2003 .10 .002

53. Krishnamurthy, S. (2007). Reflexive inquiry and reflective practice: Critical reflection and pedagogy in English language teaching. Nawa: Journal of Language and Communications, 1(2), 14-22.

54. Lee, H. J. (2005). Understanding and assessing preservice teachers' reflective thinking. Teaching and Teacher Education, 21(6), 699-715. https://doi.org/10.1016/j.tate.2005.05.007

55. Liashenko, I. (2020). Reflective practice as means of critical thinking development in distance learning with university students. ICV 2019, 79(31), 308-315, https://doi.org/10.31494/2412-9208-2020-1-3-308-315

56. Lieberman, A. \& Miller, L. (2000). Teaching and teacher development: A new synthesis for a new century. In Education in a New Era, Brandt, R. (ed.), (pp. 47-66).

57. Lunenberg, M., Korthagen, F., \& Swennen, A. (2007). The teacher educator as a role model.Teaching and Teacher Education, 23(5), 586-601. https://doi.org/10.1016/j.tate.2006.11.001

58. Mason, J. (2012). Scaffolding reflective inquiry - enabling why-questioning while e-learning. Research and Practice in Technology Enhanced Learning, 7(3), 175-198

59. McAdams, D.P. (1993). Power, intimacy and the life story: Person logical inquiries into identity. New York, NY: Guilford.

60. McAlPINE, L. (2016). Why might you use Narrative Methodology? A Story about Narrative, Eesti Haridusteaduste Ajakiri, 4(01), 32-37. https://doi.org/10.12697/eha.2016.4.1.02b

61. Merriam, S. B. (2002). Introduction to qualitative research. In S. B. Merriam (Ed.), Qualitative research in practice: Examples for discussion and analysis (pp. 3-17). San Francisco, CA: Jossey-Bass.

62. Moradkhani, S. \& Shirazizadeh, M. (2017). Context-based variations in EFL teachers' reflection: the case of public schools versus private institutes in Iran. Reflective Practice, 18(2), 206-218 https://doi.org/10.1080/ 14623943.2016 .1267002

63. Pardo, A.N \& Téllez, M. F.T. (2015). Reflection on teachers' personal and professional growth through a materials development seminar. HOW, 22(2), 54-74. https://doi.org/10.19183/how.22.2.151

64. Pinnegar, S \& Daynes, J. (2007). 'Locating narrative inquiry historically: Thematics in the turn to narrative', in D J Clandinin (ed), Handbook of narrative inquiry: Mapping a methodology, SAGE Publications, Thousand Oaks, California, pp. 3-34. https://doi.org/10.4135/9781452226552.n1

65. Polkinghorne, D. E. (1995) Narrative configuration in qualitative analysis. In Life history and Narrative. Edited by J. Amos Hatch and Richard Wisniewski. Falmer Press: London. 
66. Polkinghorne, D.E. (1988). Narrative knowing and the human sciences. Albany, NY: The State University of New York Press.

67. Postareff, L., Katajavuori, N., Lindblom-Ylanne, S., \& Trigwell, K. (2008). Consonance and dissonance in descriptions of teaching of university teachers. Studies in Higher Education, 33(01), 49-61. https://doi.org/10. $\underline{1080 / 03075070701794809}$

68. Rahimi, M \& Weisi, H. (2018). Reflective practice, self-efficacy and research practice of EFL teachers: Examining possible relationships, Issues in Educational Research, 28(3), 756-780. http://resig.weebly.com/uplo ads/2/6/3/6/26368747/smith_2014

69. Reis-Jorge, J. (2007). Teachers' conceptions of teacher-research and self-perceptions as enquiring practitioners: A longitudinal study. Teaching and Teacher Education, 23(4), 402-417. https://doi.org/10.10 16/j.tate.2006.12.007

70. Riessman, C. K. (2002). Analysis of personal narratives. In Handbook of Interview Research. Edited by Jaber F. Gubrium and James A Holstein. Sage Publications. 695-709. https://doi.org/10.4135/9781412973588.n40

71. Rolfe, G., Freshwater, D., \& Jasper, M. (2001). Critical Reflection for Nursing and the Helping Professions: A user's guide. London: Palgrave Macmillan.

72. Sahin, F., \& Usta, G. S. (2014). The effects of reflective inquiry-based activities on preservice science teachers' biology laboratory concerns and critical thinking dispositions. The Journal of SAU Education Faculty, 27(5), 25-50.

73. Sahoo, P. K., \& Pany, S. (2020). Exploring methods for reflective thinking: Synthesis of reviews. Pedagogy of Learning, 6 (4), 34-41. Retrieved from: http://pedagogyoflearning.com

74. Schön, D. (1996). Educating the reflective practitioner: Toward a new design for teaching and learning in the professions. San Francisco: Jossey-Bass.

75. Slade, M. L., Burnham, T. J. D., Catalana, S. M., \& Waters, T. (2019). The impact of reflective practice on teacher candidates' learning, International Journal for the Scholarship of Teaching and Learning, 13(2), Article 15. https://doi.org/10.20429/ijsotl.2019.130215

76. Toom, A., Husu, J. \& Patrikainen, S. (2015). Student teachers' patterns of reflection in the context of teaching practice. European Journal of Teacher Education, 38(3), 320-340. https://doi.org/10.1080/0 2619768.2014 .943731

77. Ukrob,M., Śvábenský.V., Nehyba „J.(2018). Reflective diary for professional development of novice teachers, arXiv:1811.02965v1 (cs.CY) 7 Nov 2018.

78. Wang, C. C., \& Geale, S. K. (2015). The power of story: Narrative inquiry as a methodology in nursing research. International Journal of Nursing Sciences, 2(1), 195-198. https://doi.org/10.1016/j.ijnss.2015.04.014

79. Watson, M. (2014). Bad Kids Gone Good: A Narrative Inquiry Study of Alternative Education Graduates, Texas: A\&M University-Corpus Christi Corpus Christi.

80. Yanuarti, E \& Treagust. D.F. (2016). Reflective Teaching Practice Teachers' Perspectives in an Indonesia Context, The authors - Published by Atlantis Press, 280-284. https://doi.org/10.2991/icse-15.2016.60

81. Yost, D.S., \& Mosca, F.J. (2003). The E. N. A. C. T Model: Enhancing Teacher candidate's ability to manage student behavior, Teacher Education and Special Education, 26(4), 349-355. https://doi.org/10.117 7/088840640302600410

82. Zahid, M, and Khannum, A. (2019). Effect of Reflective Teaching Practices on Performance of Prospective Teachers. The Turkish Online Journal of Educational Technology, 18(01), 32-43.

83. Zilber, T.B., Tuval-Mashiach, R., \& Lieblich, A. (2008). The embedded narrative: Navigating through multiple contexts. Qualitative Inquiry, 14(6), 1047-1069. https://doi.org/10.1177/1077800408321616 